\begin{tabular}{|c|c|c|}
\hline ISSN (Online): 2367-6957 & $67-6957$ & ISSN (Print): 2367-6361 \\
\hline & Izvestiya Journal of Varna University of Economics 1 (2021) & VESTIYA \\
\hline & IZVESTIY A & $=$ \\
\hline D. & $\begin{array}{c}\text { Journal of Varna University of Economics } \\
\text { http://journal.ue-varna.bg }\end{array}$ & 6 \\
\hline
\end{tabular}

\title{
EARLY MARRIAGE AS A DETERMINANT OF POVERTY IN NIGERIA
}

\section{Adenuga ADEKOYA ${ }^{1}$, Gbenro SOKUNBI ${ }^{2}$}

1 Department of Economics, School of Arts and Social Sciences, Michael Otedola College of Primary Education, Noforija-Epe, Lagos, Nigeria. E-mail: adenugaadekoya@gmail.com

2 Department of Economics, School of Arts and Social Sciences, Michael Otedola College of Primary Education, Noforija-Epe, Lagos, Nigeria. E-mail: adegbenro2008@yahoo.com

JEL: J12, I32, I38

\section{Key words:}

early marriage, poverty, social welfare.

\begin{abstract}
A greater percentage of women in developing countries married before their 18th birthday. Early marriage serves as a threat to a child's future development. This is because it is difficult to have access to quality education and higher education, and it limits the ability to secure a good job. Also, girls involved in early marriage face acute poverty conditions. This research examined the link between early marriage and poverty in Nigeria. Annual data is sourced from 1970 to 2017 . Granger causality is used to determine the nature of causality.

Autoregressive Distributed Lagged Model is further used to estimate the data. The result showed that a bi-directional Granger causality exists between early marriage and poverty as well as for low-income and early marriage. In the long-run estimation, early marriage, secondary education and low-income increase poverty. Also, social welfare and access to credit facilities reduce poverty. The policy makers are therefore encouraged to improve social welfare for girls in early marriage and provide easy access to credit facilities for them to pursue higher education or entrepreneurship skills, in a bid to gradually move them out of poverty.
\end{abstract}

(C) 2021 University of Economics - Varna

Citation: ADEKOYA, A., SOKUNBI, G. (2021). Early Marriage as a Determinant of Poverty in Nigeria. Izvestiya Journal of Varna University of Economics, 65 (1), pp. 102 - 119. DOI: 10.36997/IJUEV2021.65.1.102 
A. Adekoya, G. Sokunbi.

Early Marriage as a Determinant of Poverty in Nigeria

\section{Introduction}

Efforts to reduce poverty in the world became part of the issue in the 2030 sustainable development agenda; this is because poverty is one of the worst threats and challenges to human welfare especially in low-income countries (United Nations, 2018). Part of these efforts include boosting agriculture and increasing trade integration to drive economic growth (The World Bank, 2017). In spite the benefits of growth policy received by the poor population in Africa between 2000 and 2016; their consumption growth did not make them escape poverty compared to other developing countries outside Africa (African Economic Outlook, 2020). Also, the extreme poverty rate by region for 2015 showed that Sub-Saharan Africa had 41.1\%, which is above South Asia 12.4\%, Latin America and the Caribbean 4.1\% and the World 10\% (The World Bank, 2018), while the poverty headcount rate in 2019 for Nigeria stood at $40.09 \%$ (Nigeria Bureau of Statistics, 2019). With the increase in the population of Nigeria, the nation may likely be the country with the poorest people (The World Bank, 2018).

One of the means of increasing the population in Nigeria and other Sub-Saharan Africa developing countries is early marriage through the increase in the fertility rate (Yaya, Odusina \& Bishwajit, 2019). In 2018, the percentage of women aged 20-24 married before the age of 15 was $15.7 \%$ in Nigeria, $9.4 \%$ in Benin, $15.9 \%$ in Mali, $5.2 \%$ in Zambia and $12.7 \%$ in Madagascar. Those who married at the age of 18 stood at $43.4 \%$ in Nigeria, $30.6 \%$ in Benin, $53.7 \%$ in Mali, $29 \%$ in Zambia and $13.7 \%$ in Morocco (United Nations Children Education Fund (UNICEF), 2020).

The consequences of early marriage are many. First, it lowers educational opportunities for the affected girl child (Brown, 2012). Once they get married, they immediately assume the role of a mother, which in turn forces them to drop out of school. The young brides miss the social skills, formal knowledge, necessary friendship and networks, which the school provides (UNICEF, 2014). Second, early marriage makes the child spouses sad from the first day of the marriage. This is because the bride is not aware of the situation and circumstances around her. She cannot make informed decisions, neither does she have full knowledge of the man she is married to (Adekola, Akanbi \& Olawole-Isaac, 2015). Third, child marriages have an effect on the nation's welfare package in Nigeria. This is due to the fact that the high population growth rate poses challenges and necessitates an update of developmental plans. Hence, government efforts aimed at providing basic social services to improve the lives of the populace may not yield the desired results. Accessing the available essential services therefore becomes the issue of survival of 
the fittest. Lastly, there is the possibility of being a single parent as a result of accepting forced cohabitation with a man. The affected girl child faces the problems of stigmatization and social exclusion in life. This and other hidden consequences promote inequality in gender. (Adeyanju \& Afolayan, 2012). The inequality in gender may encourage a poverty trap for the girl child in early marriage.

In unravelling whether early marriage causes poverty, this study answered the research question. That is, will early marriage reduce poverty or breed more poverty? The question deserved a place in the literature because of the need for this study. Firstly, the human right violation targeted at the girl child must be reduced. Secondly, the girl child must be afforded the opportunity to receive quality education and live a healthy life. Thirdly, child marriage and its attendant consequences must be eradicated or at least reduced to the barest minimum in order to achieve the 2030 agenda thereby promoting sustainable development. (The Save the Children Fund, 2018 and United Nations Children's Fund, 2014).

This study contributed to the literature in a number of ways. To start with, early marriage is positive to determine poverty. This means early marriage is an impediment to poverty reduction. Similarly, financial development and social welfare programmes minimize early marriage and poverty. Furthermore, the empirical link between early marriage and poverty is novel in the literature. Also, it poses recommendations to the policy makers on how poverty may be reduced in Nigeria and other developing nations. The remaining part of the paper is divided into four sections; Section 2 discusses the literature review, Section 3 focuses on the research method, while Section 4 presents the estimated result and Section 5 is the conclusion.

\section{Literature Review}

\subsection{Conceptual Review}

Child marriage is a form of marriage whereby the spouses are less than 18 years old at the time of contracting the marriage (Parsons et al., 2019; Adekola et al., 2015 \& International Center for Research on Women (ICRW), 2006). For a deeper and clearer understanding, the International Planned Parenthood Federation (IPPF, 2007) described child marriage as a form of marriage contracted below the age of 18 years, especially before the girl spouse is matured physically, physiologically, and psychologically and fully ready to shoulder the responsibilities of marriage and child bearing."

Early marriages are usually organized in two different forms, through certain degree of force and intimidation, either by the girl parents or other powerful 
A. Adekoya, G. Sokunbi.

Early Marriage as a Determinant of Poverty in Nigeria

individuals in the family who perfect the marriage arrangement of the girl child to an adult man (Adedokun, Tochukwu \& Adedeji, 2012). It is noteworthy that in choosing the most prospective husbands, some factors, such as monetary, religious, social status, etc. are usually the point of attraction. The age difference between the husband and the girl child is not usually considered (Population Council, 2008).

Although the minimum marriage age ranges from one country to the other, the internationally acclaimed and acceptable age is eighteen years, as entrenched in the various conventions and edicts. That is why child marriage is in most cases usually accompanied by some degree of coercion, because a female child is involved. In this case the feeling, emotion, consent, love, education, aspiration, interest, etc. of the bride child is not taken into consideration. It is usually an arranged form of marriage, especially with the consent of the child bride parent or their representative.

The need to have a standardized marriage age across the board has generated some form of argument among scholars. While some supported the idea, others opined that each country should be allowed to determine the minimum marriageable age, with special attention to the girl child. Therefore, Bunting (1999) proposes that governments should be permitted to fix the age of marriage below 18 years of age, but they should further ensure that the reduced age does not in any way discriminate against women or bring any adverse consequences for them.

Girls Not Brides (2018) observed that child marriage is being encouraged by gender disparity and the notion that boys are stronger and more important than girls. In Nigeria for instance, child marriage is mostly observed in the North West and North East. The menace is more pronounced among Nigeria's poorest, rural households and the Hausa ethnic group. Other factors, according to scholars, that promote child marriage, are the low level of education of girl children, political and economic ties, poverty, violence against girls, gender norms, etc.

The successive Nigerian governments have demonstrated some degree of commitment to deal with the issue decisively and probably eliminate early/child marriage. For instance, the country in 1985 ratified the Convention on the Elimination of All Forms of Discrimination against Women (CEDAW) as well as the Convention on the Rights of the Child in 1991. In 2001 Nigeria ratified the African Charter on the Rights and Welfare of the Child, including Article 21, regarding the prohibition of child marriage and the African Charter on Human and People's Rights on the Rights of Women in Africa, including Article 6 which sets the minimum age for marriage as 18 in 2004. Most recently, in 2014, Nigeria signed a joint statement at the Human Rights Council calling for a resolution on child marriage and launched the African Union Campaign to End Child Marriage in Africa in 2016. 
As laudable as these programs seem, and the few other physical government efforts, one major impediment to the eradication of child marriage remain the political will and power to enforce these laws (especially at the state and district levels) at the expense of the religions, customs and traditions of the people.

\subsection{Empirical Review}

Researchers, scholars and notable national and international organizations have contributed to the growing debates on early marriage across the globe. The efficacy of the menace was emphasized when Lemmon and ElHarake (2014) noted that the incidences of child marriage go beyond geographical and national territories and are not restricted to any particular religion, custom or tradition.

Nzenwata (2018) examined the variables that invigorate the practice of child marriage and its effects on Nigerian society. She used 296 self-administered questionnaires to females between the ages of 10-45 years in Kastina State, the Northern part of Nigeria where early girl-child marriage is significantly high. The result showed that early girl-child marriage has a negative effect on Nigeria. The study recommended a feasible and applicable way forward to abolish and manage the victims of early girl-child marriage. Similarly, Kyari and Ayodele (2014) examined the socio-economic effect of early marriage in north western Nigeria using Zaria Local Government as a case study. The results showed that early marriage has a negative effect on girl-child education. Notably among these effects is high poverty rates for households as a result of losses in revenues and increased basic needs of larger family sizes (Wodon, Montenegro, Nguyen \& Onagoruwa, 2018). Other effects of child marriage according to Bala (2003) are physical, mental and emotional distress, early widowhood, Vesico Vaginal Fistula (VVF) disease, hatred for the man, school drop-out, frustration and intolerance. Furthermore, Roest (2016) observed that Poverty and social disadvantage are key factors limiting the girl child's prospects and aggravate their risks in life. Generally speaking, early marriage deprives the child brides of their basic rights, which eventually disempowers them in many ways in society.

Khandaker and Shah Md (2015) studied the relationship between extreme weather events and early marriage and violence. Two districts that are prone to flood were selected as the population of the study. Data were collected from 120 household heads while some descriptive statistics and qualitative analysis were used in the data analysis. The findings from the study revealed that most household heads thought that early marriage is poverty coping mechanism. It further reduces their fear of harassing their young girls sexually during extreme weather events. Early marriage was 
therefore seen as a means of protecting their family reputation because of fear of sexual harassment during the crises period. In the opinion of Bayisenga (2012), people engaged in early marriage due to religious and socio-cultural values, the search for economic survival, protection of young girls, wars and civil conflicts, controlling female behavior and sexuality, as well as peer group and family pressure. Reuben (2014) studied the causes and effects of early marriage on the girl-child in Suba, a Sub-County in Kenya. It was guided by radical feminist theory and gathered data through the survey method, focus group discussions, direct observation, key informant interviews and narratives. The study found that girls drop out of school at an early age due to poverty and end up marrying early because of not having anything meaningful to do.

Giyan (2009) observed that some religious practices encourage early marriage. In most cases, those that practice the religion usually adopt the practice so as to prevent their girl child from being pregnant out of marriage. Hence, one major available option will be to marry at an early age. In Nigeria for instance, it has been argued that Islamic religion permits and supports early marriage, with a caution that the bride must be mature enough. Lloyd et.al. (2006) further noted that the need to preserve the girl's virginity so that the family can earn the desired honour and respect in society is an important factor that influences the parents' choice of supporting the early marriage of their daughters. This is more pronounced in the primitive traditional societies, where the issue of morality, respect and honour are held in high regard. Marrying young daughters to older men was also seen as a means of safeguarding the child bride against potential decadent and inappropriate behavior. Abdallah (2011) observed that child marriage is a common phenomenon in Nigeria, which is strongly tied to the culture, custom, religion and tradition of the people. The menace therefore had resting pillars, which continue to provide a shield for its perpetrators, despite the tremendous efforts of the government and other concerned national and international bodies.

The review of previous studies has shown that numerous factors (with multiplying effects) account for child marriages in the various parts of the world, Nigeria inclusive. These factors however, need to be put on check through deliberate and concerted efforts of all concerned individuals and bodies. The government at all levels must display some degree of seriousness by giving the desired attention to girl children and women. Doing this will prepare and sustain the nation towards achieving the United Nations Sustainable Development Goals. 


\section{Research Method}

\subsection{Data}

To test the link between early marriage and poverty, this study used annual data from 1970 to 2017. The variables are defined in Table 1, while Table 2 presents the description of the data. Moreover, the poverty rate and the low-income rate followed the disadvantage index approach used in Mata and Bollman (2007). Adolescent fertility from Age $15-19(\%)$ is similar to the maternal age at child bearing used in Dahinten, Shapka and Willms (2007). Secondary education studied in Ogundari and Aromolaran (2014) as financial development studied in Rewilak (2017) while Social Welfare studied in Kenworthy (1999).

Table 1

\section{Definitions of variables}

\begin{tabular}{|c|c|c|c|}
\hline Variables & Definition & Expected sign & Source \\
\hline Poverty rate $\left(\mathrm{POVH}_{t}\right)$ & $\begin{array}{l}\text { The inverse of } \\
\text { logarithm of per } \\
\text { capita household } \\
\text { consumption } \\
\text { multiply by } 100\end{array}$ & + & $\begin{array}{l}\text { Economics and } \\
\text { Research } \\
\text { Department, United } \\
\text { Nations. }\end{array}$ \\
\hline Early marriage $\left(E M_{t}\right)$ & $\begin{array}{l}\text { Early/child marriage } \\
\text { proxy by adolescent } \\
\text { fertility from Age } 15 \\
-19(\%)\end{array}$ & + & $\begin{array}{l}\text { World Development } \\
\text { Indicator }\end{array}$ \\
\hline Secondary education $\left(S E D_{t}\right)$ & $\begin{array}{l}\text { The logarithm of } \\
\text { enrolment in } \\
\text { secondary schools }\end{array}$ & + & $\begin{array}{l}\text { Nigeria Bureau of } \\
\text { Statistics }\end{array}$ \\
\hline Low-income rate $\left(L Y_{t}\right)$ & $\begin{array}{l}\text { The inverse of } \\
\text { logarithm of per } \\
\text { capita income } \\
\text { multiply by } 100\end{array}$ & + & $\begin{array}{l}\text { Economics and } \\
\text { Research } \\
\text { Department, United } \\
\text { Nations. }\end{array}$ \\
\hline Financial development $\left(F D_{t}\right)$ & $\begin{array}{l}\text { Measured by } \\
\text { domestic credit } \\
\text { provided by financial } \\
\text { sector }(\% \text { of GDP) }\end{array}$ & - & $\begin{array}{l}\text { World Development } \\
\text { Indicator }\end{array}$ \\
\hline Social Welfare $\left(S W_{t}\right)$ & $\begin{array}{l}\text { Proxy by logarithm } \\
\text { of Social Services to } \\
\text { Community } \\
\text { Expenditure which } \\
\text { includes health, } \\
\text { education and others. }\end{array}$ & - & $\begin{array}{l}\text { Central Bank of } \\
\text { Nigeria }\end{array}$ \\
\hline
\end{tabular}


Table 2

\section{Data description}

\begin{tabular}{|c|r|r|r|r|r|r|}
\hline Variables & \multicolumn{1}{c|}{ Mean } & Median & Maximum & Minimum & $\begin{array}{c}\text { Standard } \\
\text { Deviation }\end{array}$ & Observations \\
\hline$P O V H_{t}$ & 8.3328 & 8.3684 & 8.5936 & 8.0117 & 0.1779 & 47 \\
\hline$E M_{t}$ & 144.0014 & 142.0736 & 172.0360 & 109.2740 & 20.2624 & 47 \\
\hline$S E D_{t}$ & 14.9293 & 15.1621 & 16.3451 & 12.6445 & 0.97355 & 47 \\
\hline$L Y_{t}$ & 8.0459 & 8.0489 & 8.2911 & 7.7758 & 0.1591 & 47 \\
\hline$S W_{t}$ & 7.8969 & 7.3358 & 12.3146 & 1.4350 & 2.3944 & 47 \\
\hline$F D_{t}$ & 13.3583 & 12.9997 & 38.3865 & 4.6995 & 6.3020 & 47 \\
\hline
\end{tabular}

\subsection{Model specification}

In establishing whether a link exists between early/child marriage and poverty, this research adopts a typical household utility model in equation 1, it is a reduced form of the earnings function employed to determine the impact of education on household welfare. In the model, per capita total expenditure measured household welfare (Ogundari \& Aromolaran, 2014). In equation 1, $P C E_{t}$ is the per capita monthly total expenditure on food and non-food items, $X_{t}$ is the vector of explanatory variables (determinants) used to explain $P C E_{t} ; \beta$ is a parameter and it describes effect of $X_{t}$ on $P C E_{t}$ while $\mu_{t}$ is the white noise which indicates the residual in the model.

$$
P C E_{i}=\beta X_{i}+\mu_{t}
$$

The model in equation 1 suits the intention of this research as presented in equation 2 because the dependent variable in this study measured inverse of per capita household consumption $\left(\mathrm{POVH}_{t}\right)$, which depend on education at various levels. Likewise, this study used education at secondary level $\left(S E D_{t}\right)$ as included in the model in equation 1 . Thus, the model modified to study early marriage $\left(E M_{t}\right)$ while controlling for low-income rate $\left(L Y_{t}\right)$, social welfare $\left(S W_{t}\right)$ and financial development $\left(F D_{t}\right) . \beta_{0}$ is constant, $\beta_{1}, \beta_{2}, \beta_{3}, \beta_{4}$ and $\beta_{5}$ are parameters as $\mu_{t}$ is the white noise. $\beta_{1}, \beta_{2}$ and $\beta_{3}$ are expected to increase poverty while $\beta_{4}$ and $\beta_{5}$ are expected to reduce poverty.

$$
P O V H_{t}=\beta_{0}+\beta_{1} E M_{t}+\beta_{2} S E D_{t}+\beta_{3} L Y_{t}+\beta_{4} S W_{t}+\beta_{5} F D_{t}+\mu_{t}
$$




\subsection{Time series property of the data}

Time series data are associated with distortion especially from its lagged values; it often occurred due to socio-economic happenings, a situation that makes regression spurious and therefore led to misleading results. This is because time series are not stationary in nature. To avoid these problems, the Augmented Dickey-Fuller (ADF) unit root test was conducted. All variables in the model passed this test at the 5\% level of significance (see Dickey \& Fuller, 1981). The ADF unit root test applied to the order of integration of the variables at level and first differences with intercept and trend. The result presented in Table 2 showed that only early marriage is at level while other variables are at first difference.

Table 3

\section{Results of the Unit Root Test}

\begin{tabular}{|c|c|c|r|r|c|}
\hline \multicolumn{7}{|c|}{ Augmented Dickey-Fuller (ADF) } \\
\hline Variables & ADF Model & $\begin{array}{c}\text { Lag } \\
\text { length }\end{array}$ & ADF statistics & Prob. Value & Decision \\
\hline $\boldsymbol{P O V} \boldsymbol{H}_{\boldsymbol{t}}$ & Intercept and trend & 1 & -9.879 & 0.000 & $\mathrm{I}(1)$ \\
\hline $\boldsymbol{E} \boldsymbol{M}_{\boldsymbol{t}}$ & Intercept and trend & 0 & -3.662 & 0.035 & $\mathrm{I}(0)$ \\
\hline $\boldsymbol{S E D}$ & Intercept and trend & 1 & -8.188 & 0.000 & $\mathrm{I}(1)$ \\
\hline $\boldsymbol{L} \boldsymbol{Y}_{\boldsymbol{t}}$ & Intercept and trend & 1 & -6.033 & 0.000 & $\mathrm{I}(1)$ \\
\hline $\boldsymbol{S} \boldsymbol{W}_{\boldsymbol{t}}$ & Intercept and trend & 1 & -7.168 & 0.000 & $\mathrm{I}(1)$ \\
\hline $\boldsymbol{F} \boldsymbol{D}_{\boldsymbol{t}}$ & Intercept and trend & 1 & -5.562 & 0.000 & $\mathrm{I}(1)$ \\
\hline $\boldsymbol{D} \boldsymbol{I}_{\boldsymbol{t}}$ & Intercept and trend & 1 & -6.483 & 0.000 & $\mathrm{I}(1)$ \\
\hline
\end{tabular}

Note: the figures reported are t-ratio and showed the p-values of MacKinnon (1996) one-sided at various levels of significance. The asterisks $(* * *)$ is at $1 \%$.

From the above, it is discovered that there is a mixture of integration of $\mathrm{I}(0)$ and $\mathrm{I}(1)$ in the ADF test. In addition, there is a tendency for early marriage among teenagers to encourage poverty; and the same time families that experience poverty gave their children for marriage early. This suggests the two variables are endogenous. Besides, Pesaran, Smith and Shin (2001) proposed that the autoregressive distributed lagged model (ARDL) suits estimation of variables integrated at $\mathrm{I}(0)$ and $\mathrm{I}(1)$. It is also good to estimate variables that are endogenous because it uses a period lag of the dependent variable in the model; it helps to minimize the problem of endogeneity once it found that there is no serial correlation. Further, it provides room to test whether serial correlation exists in the model (Pesaran and Shin, 
1997). Narayan (2005) argued ARDL fit to test small sample size. In view of these advantages of ARDL, this study employed its usage and the model in equation 1 transformed into an ARDL framework as presented in equation 2.

$$
\begin{aligned}
\Delta \mathrm{POVH}_{t} & =\beta_{0}+\beta_{1} \mathrm{POVH}_{t-1}+\beta_{2} E M_{t-1}+\beta_{3} S E D_{t-1}+\beta_{4} L Y_{t-1}+\beta_{5} S W_{t-1} \\
& +\beta_{6} F D_{t-1}+\sum_{i=1}^{p} \gamma_{1} \Delta P O V H_{t-1}+\sum_{i=0}^{p} \gamma_{2} \Delta E M_{t-1}+\sum_{i=0}^{p} \gamma_{3} \Delta S E D_{t-1} \\
& +\sum_{i=0}^{p} \gamma_{4} \Delta L Y_{t-1}+\sum_{i=0}^{p} \gamma_{5} \Delta S W_{t-1}+\sum_{i=0}^{p} \gamma_{6} \Delta F D_{t-1}+\mu_{t}
\end{aligned}
$$

Liew (2004) concluded that in testing a small sample size, the Akaike Information Criterion (AIC) is preferable because it ensures the dynamic transformation of the model. Based on AIC, the lag selection are determined and specified as ARDL $(1,1,0,0,0,0)$ (see Table 3). The cointegration test was conducted with the F-statistic in the bound test. The F-statistic allowed for a joint test of series in the model at one period of lag to determine the presence of co-integration in the long-run. Sequel, this joint significance is based on the null hypothesis of no co-integration where $H_{0}: \beta_{1}=\beta_{2}=\beta_{3}=\beta_{4}=\beta_{6}=\beta_{6}=0$ (implies non-existence of cointegration) and the alternative is $H_{1}: \beta_{1} \neq \beta_{2} \neq \beta_{3} \neq \beta_{4} \neq \beta_{5} \neq \beta_{6} \neq 0$ and where at least one of the $\beta_{1}$ to $\beta_{6} \neq 0$ (implies the existence of cointegration) in equation 2. Besides the $\gamma_{1}, \gamma_{2}, \gamma_{3}, \gamma_{4}, \gamma_{5}$ and $\gamma_{6}$ are the shortrun coefficients. Thus, there is cointegration among the variables as presented in Table 4 .

\section{Results and Discussion}

Earlier, this study observed that there is a possibility that poverty and early marriage may be endogenous. To ascertain this, a pairwise Granger causality is tested, the result is presented in Table 3. The result showed that there is a bi-directional causality between early marriage and poverty, which confirms the endogeneity in the model tested. That is, current values of poverty are affected by past values of early marriage and thus, vice versa. Similarly, a bi-directional causality exists between low income and early marriage. However, a unidirectional causality ran from low income to secondary education and from low income to social welfare. Further, the causality ran from social welfare to early marriage, and financial development to early marriage.

Being fully aware that there is endogeneity bias in the model and also that the model comprised of mixture of integrated series of I(0) and I(1), ARDL became the best model to estimate the data in this study. The result of the estimation through ARDL is presented in Table 4. It comprises of long run and short run as well as the 
diagnostic tests. Further, the F-test calculated is above the critical F-test at the 1\% level of significance, which indicates a joint movement exist among the variables based on the AIC specified for the ARDL transformation.

Table 4

\section{Results of the Pairwise Granger causality test}

\begin{tabular}{|c|c|c|c|c|c|}
\hline Null Hypothesis & $k$ & Obs & $F-$ stat & P.value & Decision \\
\hline$E M_{t}$ does not Granger cause POVH & 1 & 46 & 7.536 & $0.008 * * *$ & \multirow{2}{*}{$\begin{array}{c}\boldsymbol{E M} \leftrightarrow \boldsymbol{P O V H} \\
\text { Bi-directional }\end{array}$} \\
\hline $\mathrm{POVH}_{t}$ does not Granger cause EM & 1 & 46 & 12.591 & $0.000 * * *$ & \\
\hline$L Y_{t}$ does not Granger cause POVH & 1 & 47 & 0.080 & 0.777 & \multirow{2}{*}{$\begin{array}{l}P O V H \rightarrow L Y \\
\text { Unidirectional }\end{array}$} \\
\hline $\mathrm{POVH}_{t}$ does not Granger cause $L Y_{t}$ & 1 & 47 & 10.230 & $0.002 * * *$ & \\
\hline$L Y_{t}$ does not Granger cause $E M_{t}$ & 1 & 46 & 7.537 & $0.008 * * *$ & \multirow{2}{*}{$\begin{array}{c}\boldsymbol{L Y} \leftrightarrow \boldsymbol{E} \boldsymbol{M} \\
\text { Bi-directional }\end{array}$} \\
\hline$E M_{t}$ does not Granger cause $L Y_{t}$ & 1 & 46 & 3.621 & $0.063 *$ & \\
\hline$S W_{t}$ does not Granger cause $E M_{t}$ & 1 & 46 & 7.022 & $0.011^{* *}$ & \multirow{2}{*}{$\begin{array}{c}\boldsymbol{S W} \rightarrow \boldsymbol{E M} \\
\text { Unidirectional }\end{array}$} \\
\hline$E M_{t}$ does not Granger cause $S W_{t}$ & 1 & 46 & 0.313 & 0.578 & \\
\hline$F D_{t}$ does not Granger cause $E M_{t}$ & 1 & 46 & 3.674 & $0.061 *$ & \multirow{2}{*}{$\begin{array}{c}\boldsymbol{F D} \rightarrow \boldsymbol{E M} \\
\text { Unidirectional }\end{array}$} \\
\hline$E M_{t}$ does not Granger cause $F D_{t}$ & 1 & 46 & 0.925 & 0.341 & \\
\hline$L Y_{t}$ does not Granger cause $S E D_{t}$ & 1 & 47 & 3.850 & $0.056^{*}$ & \multirow{2}{*}{$\begin{array}{c}\boldsymbol{L Y} \rightarrow \boldsymbol{S E D} \\
\text { Unidirectional }\end{array}$} \\
\hline$S E D_{t}$ does not Granger cause $L Y_{t}$ & 1 & 47 & 0.268 & 0.606 & \\
\hline$S W_{t}$ does not Granger cause $L Y_{t}$ & 1 & 47 & 0.102 & 0.750 & \multirow{2}{*}{$\begin{array}{c}\boldsymbol{L Y} \rightarrow \boldsymbol{S W} \\
\text { Unidirectional }\end{array}$} \\
\hline$L Y_{t}$ does not Granger cause $S W_{t}$ & 1 & 47 & 7.207 & $0.010 * *$ & \\
\hline
\end{tabular}

Note: $k$ is the lag length in the model as the asterisks $*$ is at the $1 \%(* * *), 5 \%(* *)$ and $10 \%$ level of significance.

Table 5 showed the long-run estimated results. Early marriage is significant to determine poverty at the $1 \%$ level of significance. A $1 \%$ increase in early marriage causes $0.01 \%$ increase in poverty. This result answered the research question that early marriage breeds more poverty. Secondary education is positive to determine poverty at the $1 \%$ level of significance. That is, $1 \%$ increases in secondary education 
causes $0.14 \%$ increase in poverty. This result supports Ogundari and Aromolaran (2014) that found that return on secondary education is lower to enhance per capita consumption when compared to return on tertiary education. Similarly, this study detected that low-income rate is significant to determine poverty at the $1 \%$ level of significance. This means that when the population with low-income increased by $1 \%$, this gave rise to $0.52 \%$ in poverty. Results on low-income corroborate Fonta, Nkwenkeu, Lath, Hollebecque, Ouedraogo, and Sirajo (2018). Fonta et al., (2018) concluded that access to an increase in the source of income reduces the chances of poverty severity. That is, when the source of income is poor, it encourages the children of such families to feed poorly and have poor access to education and health. The social welfare is a viable measure to reduce poverty significantly at the $1 \%$ level of significance. It means that when social welfare policy increases by $1 \%$, there is a certainty that poverty would reduce by $0.03 \%$. This result supports Kenworthy (1999). The ability to have access to funds through financial development is viable to cause reduction in poverty at the $1 \%$ level of significance. An increase of $1 \%$ in financial development creates room for $0.006 \%$ reduction in poverty. This result is in line with Rewilak (2017) who found that financial deepening and physical financial access have greater poverty reduction effect; however, it ascertained that financial instability encourages poverty as it lowers economic growth.

The result in the short-run estimation showed that early marriage and lowincome supports the result obtained in the long-run. While $1 \%$ increases in early marriage increases poverty by $0.008 \%, 1 \%$ increases in low-income increases poverty by $3.287 \%$. However, financial development portrayed it effect tool to reduce poverty as it supports the result in the long-run estimation. The error correction term $E C T_{t-1}$ is -0.803 and significant at the $1 \%$ level of significance. Disequilibrium in the model becomes stable by $80.3 \%$ in a year. This means that deviation in the short run corrected for in 1.24 years for the model to get back to equilibrium in which the full equilibrium is $100 \%$.

Table 5

Estimates of the Poverty Model based on ARDL

\begin{tabular}{|c|r|r|r|l|l|l|}
\hline \multicolumn{7}{|c|}{ Dependent variable: Poverty (POVH) } \\
\hline $\begin{array}{c}\text { Critical bounds (F- } \\
\text { test) }\end{array}$ & Lower & Upper & \multicolumn{4}{|c|}{ Test of ARDL specification significance } \\
\hline $\begin{array}{c}\text { 1\% significance } \\
\text { level }\end{array}$ & 3.06 & 4.15 & AIC* & SB & HQ & Adj-R-square \\
\hline
\end{tabular}




\begin{tabular}{|c|c|c|c|c|c|c|}
\hline $\begin{array}{c}5 \% \text { significance } \\
\text { level }\end{array}$ & 2.39 & 3.38 & 2.708 & -2.390 & -2.589 & 0.893 \\
\hline $\begin{array}{c}\begin{array}{c}10 \% \text { significance } \\
\text { level }\end{array} \\
\text {. }\end{array}$ & 2.08 & 3.00 & & & & \\
\hline F-stat & \multicolumn{2}{|r|}{8.662} & \multicolumn{2}{|c|}{ ARDL specification } & \multicolumn{2}{|c|}{$\operatorname{ARDL}(1,1,0,0,0,0)$} \\
\hline $\mathbf{K}$ & & 5 & & & & \\
\hline $\begin{array}{c}\text { Conclusion } \\
\text { (significance level) }\end{array}$ & \multicolumn{2}{|c|}{$\begin{array}{c}\text { Cointegrated } \\
(1 \%)\end{array}$} & & & & \\
\hline \multicolumn{4}{|c|}{ Long-run Estimates } & \multicolumn{3}{|c|}{ Short-run Estimates } \\
\hline & Coeffic & ents & t-statistics & & $\begin{array}{c}\text { Coefficien } \\
\text { ts }\end{array}$ & t-statistics \\
\hline$E M_{t}$ & & 0.010 & $6.584 * * *$ & $\mathrm{POVH}_{t-1}$ & -0.803 & $-6.272 * * *$ \\
\hline$S E D_{t}$ & & 0.141 & $3.949 * * *$ & $S E D_{t-1}$ & 0.113 & $4.179 * * *$ \\
\hline$L Y_{t}$ & & 0.523 & $4.941 * * *$ & $E M_{t}$ & 0.008 & $6.278^{* * *}$ \\
\hline$S W_{t}$ & & -0.031 & $-4.309 * * *$ & $L Y_{t}$ & 0.420 & $3.287 * * *$ \\
\hline$F D_{t}$ & & -0.006 & $-2.670 * *$ & $S W_{t-1}$ & -0.025 & $-3.523 * * *$ \\
\hline \multirow[t]{4}{*}{$C$} & & 0.859 & 0.963 & $F D_{t}$ & -0.005 & $-2.791 * * *$ \\
\hline & & & & $\triangle S E D_{t}$ & -0.236 & $-3.135^{* * *}$ \\
\hline & & & & $C$ & 0.690 & 0.957 \\
\hline & & & & $e c t_{t-1}$ & -0.803 & $-8.379 * * *$ \\
\hline \multicolumn{7}{|c|}{ Diagnostics Tests } \\
\hline$\left(\chi_{N}^{2}\right)$ & \multicolumn{2}{|c|}{$\left(\chi_{F F}^{2}\right)$} & \multicolumn{2}{|c|}{$\left(\chi_{S C}^{2}\right)$} & \multicolumn{2}{|c|}{$\left(\chi_{H}^{2}\right)$} \\
\hline$J B=0.072(0.964)$ & \multicolumn{2}{|c|}{$F=1.875(1.179)$} & \multicolumn{2}{|c|}{$\chi^{2}=0.928(0.335)$} & \multicolumn{2}{|c|}{$\chi^{2}=3.423(0.180)$} \\
\hline
\end{tabular}

Note: the asterisk $(*)$ showed that the estimated coefficients are significant at $1 \%(* * *)$; $5 \%\left({ }^{* *}\right)$ and $10 \%\left(^{*}\right)$ and the t-statistics are in parenthesis. Also, the diagnostic tests Normality test $\left(\chi_{N}^{2}\right)$, Functional test $\left(\chi_{F F}^{2}\right)$, Serial Correlation test $\left(\chi_{S C}^{2}\right)$ and Heteroscedasticity test $\left(\chi_{H}^{2}\right)$ are significant at $5 \%$. Variables are defined as Poverty $\left(\mathrm{POVH}_{t}\right)$ as dependent variable. Early Marriage $\left(E M_{t}\right)$, Secondary Education $\left(S E D_{t}\right)$, Low-income rate $\left(L Y_{t}\right)$, Social Welfare $\left(S W_{t}\right)$ and Financial Development $\left(F D_{t}\right)$ are independent variables. The ARDL specification is based on AIC and the F-statistic in the bounds test based on critical upper bounds. 


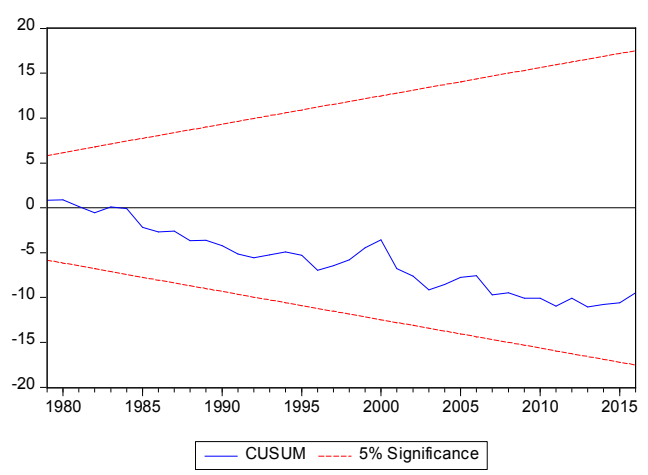

a.

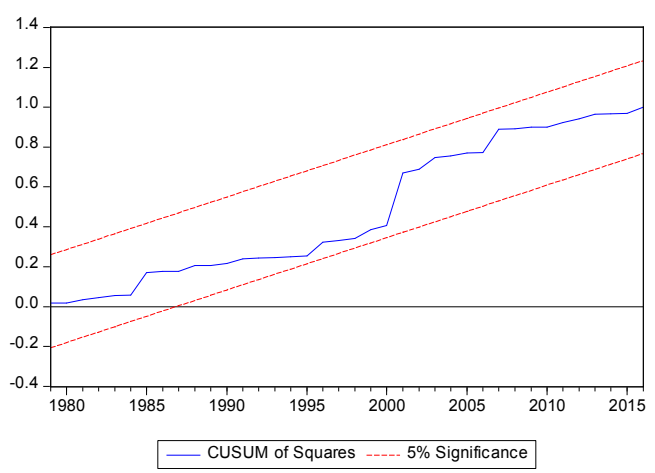

b.

\section{Figure 1. Stability Test for the Model}

Also, the diagnostic tests normality test of Jarque-Bera $\left(\chi_{N}^{2}\right)$, Ramsey's RESET functional test $\left(\chi_{F F}^{2}\right)$, LM test of Breush-Godfrey $\left(\chi_{S C}^{2}\right)$ and heteroscedasticity test of Breush-Pagan-Godfrey $\left(\chi_{H}^{2}\right)$ are significant at $5 \%$. Thus, it means that the residual is normal, no misspecification in the model. Further, it means there is no serial correlation and heteroscedasticity. In addition, the cumulative sum of recursive residuals (CUSUM) and the cumulative sum of squares of recursive residual (CUSUMSQ) indicated that the model passes these tests at 5\%. It shows that parameters in the estimated results are stable over time and thus reliable for policymaking.

\section{Conclusion and Policy Recommendation}

This paper examined the impact of early marriage on poverty in Nigeria from 1970 to 2017 . The results indicated that early marriage increases poverty. Likewise, secondary education and low income also increase poverty. Further, social welfare and financial development are capable of reducing poverty in Nigeria.

The results implied that children of low income would not attend a higher education institution. Moreover, they have chances of being poor. Lower education reduces the chances of getting a good job. Thus, enhanced income to move them out of poverty becomes scarce. It becomes difficult for a child bride with a growing family size to support the family. This invariably makes the continuous existence of a circle of poverty inevitable and exerts a greater pressure on the available welfare services.

To reduce the poverty caused by early marriage, this paper hereby suggests the following:

i. Adequate tertiary education for girl children should be compulsory in the country. 
ii. The government should improve the condition of those involved in child/early marriage. This is possible by enhancing the provision and accessibility of social welfare services.

iii. The community should assist girl children in marriages by giving them credit facilities. Such funds should be used to pursue higher education or get entrepreneurship skills and vocation. This, if properly planned and implemented, would let them have a sustainable means of livelihood, thereby gradually moving them out of poverty.

\section{References}

1. Abdallah BA (2011) Girl Child Marriage and Women Development in Nigeria: Contemporary Issues. Journal of Development and Psychology, 14(9): 248259 .

2. Adedokun GN, Tochukwu HE and Adedeji OO (2012) Early Childhood Marriage and Early Pregnancy as a Risk to Safe Motherhood. A Report on the Regional Conference on Traditional Practices Affecting the Health of Women and Children in Africa, 19-20.

3. Adekola PO, Akanbi MA and Olawole-Isaac A (2015) A Qualitative Assessment of the Effects of Child Marriage on Female Education and Entrepreneurship in Northeastern Nigeria. International Journal of Scientific Research in Multidisciplinary Studies. 2 (1): 7-15.

4. Adeyanju AB and Afolayan JA (2012) Health and Social Problem of Teenage Pregnancy and Future Child Bearing in Amassoma Community, Bayelsa State, Nigeria. Research Journal of Medical Sciences 6 (5): 251-260.

5. African Economic Outlook (2020). Developing Africa's Workforce for the Future. pp 2 pdf.

6. Brown G (2012) Out of Wedlock, Into School: Combating Early Marriage through Education. London: The Office of Gordon and Sarah Brown.

7. Dahinten VS, Shapka JD and Willms JD (2007) Adolescent Children of Adolescent Mothers: The Impact of Family Functioning on Trajectories of Development. Journal of Youth Adolescence, 36:195-212.

8. Dickey DA and Fuller WA (1981) Likelihood Ratio Statistics for Autoregressive Time Series with a Unit. Econometrica, 49(4):1057-1072.

9. Fonta, W. M., Nkwenkeu, S. F., Lath, M., Hollebecque, A., Ouedraogo, B., and Sirajo, S. (2018). Multidimensional Poverty Assessment among Adolescent Children in the Mouhoun Region of Burkina Faso, West Africa. Child Ind Res, https://doi.org/10.1007/s12187-018-9575-y. 
10. Gassman-Pines, A. and Yoshikawa, H. (2006): Five-Year Effects of an AntiPoverty Program on Marriage among Never-Married Mothers. Journal of Policy Analysis and Management, 25 (1), pp. 11-30. Brief.

11. Girls Not Brides (2018): Child Marriage in Humanitarian Settings, Thematic

12. Giyan, H. A. (2009): Women and Education: Equity and Equality. Berkley: McButcheon.

13. Hossain, M. and Islam, R. (2013). Effects of socio-economic and demographic variables on age at first marriage in Bangladesh. Current Research Journal of Biological Sciences, 5(4), pp.149-152.

14. International Center for Research on Women (ICRW). (2006) Child marriage and poverty. Washington DC: ICRW.

15. Islam, M. M., Islam, M. K., Hasan, M. S. and Haque, M. A. (2016) Marriage before 16 or 18 years: the effect of marital age on women's educational attainment in Bangladesh. Journal of Population and Social Studies, 24. Available at http://www.jpss.mahidol.ac.th/PDF/

16. Kenworthy, L. (1999). Do Social-Welfare Policies Reduce Poverty? A Cross-National Assessment. Social Forces, 77 (3), 1119-1139.

17. Khandaker, J. A. and Shah Md, A. H. (2015). Nexus between Extreme Weather Events, Marriage and Violence: A Study on a Vulnerable Population in Bangladesh, Centre for Climate Change \& Environmental Research (C3ER), BRAC University, Bangladesh.

18. Kyari, G.V. and Ayodele J. (2014): The Socio-Economic Effect of Early Marriage in North Western Nigeria: Mediterranean Journal of Social Sciences. MCSER Publishing, Rome-Italy (5) 14.

19. Lemmon, G.T. and ElHarake, L.S. (2014). Child Brides, Global Consequences-How to End Child Marriage; Council on Foreign Relations, New York, NY 10065.

20. Lloyd, C.B. and Mensch, B.S. (2006), "Marriage and Childbirth as factors in School Exit: An Analysis of DHS Data from sub-Saharan Africa", Population Council 219.

21. Nigeria Bureau of Statistics (2019). Poverty headcount rate and poverty gap indices. www.nigerianstat.gov.org

22. Nzenwata, C.B. (2018): Negative Effect of Early Girl-Child Marriage on Nigeria the Way Forward; International Journal of Scientific and Research Publications, 8 (10). 
23. Ogundari, K., and Aromolaran, A. B. (2014). Impact of Education on Household Welfare in Nigeria. International Economic Journal, 28 (2), 345-364.

24. Population Council. (2008). Child marriage in Francophone West Africa. N.Y USA.

25. Parsons, J., Edmeades, J., Kes, A., Petroni, S., Sexton, M., and Wodon, Q. (2019). Economic Impacts of Child Marriage: A Review of the Literature. The Review of Faith \& International Affairs, 13(3).

26. Reuben, M.O. (2014). Causes and Effects of Early Marriage on The GirlChild In Suba Sub - County, Western Kenya, Unpublished M.A. Thesis Submitted to The Institute Of Anthropology, Gender And African Studies, The University Of Nairobi.

27. Rewilak, J. (2017). The role of financial development in poverty reduction. Review of Development Finance, 7, 169-176.

28. Roest, (2016): Child Marriage and Early child-Bearing in India: Risk Factors and Policy implication; Policy paper 10

29. Singh, S. and Samara, R. (1996). Early Marriage among Women in Developing Countries. International Family Planning Perspectives, 22(3), pp. 100-115.

30. Smith, L., and Haddad, L. (2015). Reducing Child Undernutrition: Past Drivers and Priorities for the Post-MDG Era. World Development 68, pp. 180-204.

31. The Save the Children Fund (2018). Working together to end child marriage $7^{\text {th }}$ pp.pdf. https://resourcecentresavethechildren.net/library/working-together

32. The World Bank (2017). Annual Report 2017: End Extreme Poverty • Boost Shared Prosperity. pdf pp 18 and 20.

33. The World Bank (2018). Poverty and Shared Prosperity 2018. PovcalNet (http://iresearch.worldbank.org/PovcalNet/), World Bank. p. 42.

34. United Nations Children Education Fund (UNICEF) (2020). Child marriage data. http://.data.unicef.org/resources/dataset/child-marriage

35. UNICEF (2014). World Vision, UNHCR and Save the Children, Syria Crisis: Education Interrupted. http://www.unicef.org/media/files/Education

36. United Nations Children's Fund (2014). Ending Child Marriage: Progress and prospects, UNICEF, New York.

37. United Nations (2018). World Youth Report: Youth and the 2030 Agenda for Sustainable Development. Published by the United Nations New York, New York 10017 United States of America. pp. 1.

38. Wodon, Q., C. Montenegro, H. Nguyen, and A. Onagoruwa. (2018). Educating Girls and Ending Child Marriage: A Priority for Africa. The Cost of Not Educating Girls Notes Series. Washington, DC: The World Bank. 
A. Adekoya, G. Sokunbi.

Early Marriage as a Determinant of Poverty in Nigeria

39. Yaya, S., Odusina, E. K., \& Bishwajit, G. (2019). Prevalence of child marriage and its impact on fertility outcomes in 34 Sub-Saharan African countries. BMC International Health and Human Rights, 19 (33), pp. 848-853. 